\title{
Pengaruh Kepatuhan Wajib Pajak Terhadap Peningkatan Pendapatan Pajak Kendaraan Bermotor di Kantor Samsat Kabupaten Mamuju
}

\author{
Riswanto $^{1 *}$, Lukman Hakim ${ }^{2}$, Haerana ${ }^{3}$ \\ ${ }^{1}$ Ilmu Administrasi Negara, Universitas Muhammadiyah Makassar, Indonesia \\ ${ }^{2}$ Ilmu Administrasi Negara, Universitas Muhammadiyah Makassar, Indonesia \\ ${ }^{3}$ Ilmu Administrasi Negara, Universitas Muhammadiyah Makassar, Indonesia
}

\begin{abstract}
The purpose of this study was to determine taxpayer compliance, increase in tax revenue and the effect of taxpayer compliance on the increase in motor vehicle tax revenue at Samsat Office of Mamuju Regency. This study used quantitative. The number of samples was 99 taxpayers registered at Samsat Office of Mamuju Regenc. Data collection techniques were observation, questionnaires and documentation. The type of research used quantitative research. The results showed that there was a direct effect of taxpayer compliance on the increase in motor vehicle tax revenue at the Samsat Office of Mamuju Regency. Based on the results of the study showed that there was a positive and significant relationship so there was an effect of tax compliance $(x)$ on an increase in motor vehicle tax revenue (y) in the Samsat Office of Mamuju Regency by $54.9 \%$ and the remaining $45.1 \%$ was influenced by other variables not examined in this research. From the results of this study known that there were still several important indicators that still needed more attention to increase tax revenue in Mamuju Regency.
\end{abstract}

Keywords: taxpayer compliance, increased tax revenue

\begin{abstract}
Abstrak
Tujuan penelitian untuk megetahui kepatuhan wajib pajak di Kantor Samsat Kabupaten Mamuju, peningkatan pendapatan pajak di Kantor Samsat Kabupaten Mamuju serta pengaruh kepatuhan wajib pajak terhadap peningkatan pendapatan pajak kendaraan bermotor di Kantor Samsat Kabupaten Mamuju. Jenis penelitian yang digunakan adalah kuantitatif. Jumlah sampel yaitu 99 orang wajib pajak yang terdaftar pada Kantor Samsat Kabupaten Mamuju. Teknik pengumpulan data dengan cara observasi, kuesioner (angket), dan dokumentasi. yang digunakan Jenis penelitian yang digunakan yaitu penelitian kuantitatif. Hasil penelitian menunjukkan bahwa adanya pengaruh langsung kepatuhan wajib pajak terhadap peningkatan pendapatan pajak kendaraan bermotor di Kantor Samsat Kabupaten Mamuju. Berdasarkan hasil penelitian terdapat hubungan yang positif dan signifikan sehingga adanya pengaruh kepatuhan wajib pajak (x) terhadap peningkatan pendapatan pajak kendaraan bermotor (y) di Kantor Samsat Kabupaten Mamuju sebesar 54,9\% dan sisanya 45,1\% dipengaruhi oleh variabel lain yang tidak diteliti dalam penelitian ini. Dari hasil penelitian ini diketahui bahwa masih ada beberapa indikator penting yang masih perlu adanya perhatian lebih untuk meningkatkan pendapatan pajak di Kabupaten Mamuju.
\end{abstract}

Kata Kunci : kepatuhan wajib pajak, peningkatan pendapatan pajak

\footnotetext{
*riswan123@gmail.com
}

DOI: https://doi.org/10.26618/kjap.v6i3.4522 


\section{PENDAHULUAN}

Negara Kesatuan Republik Indonesia (NKRI) merupakan negara hukum berdasarkan Pancasila dan Undang-Undang 1945, yang memiliki tujuan mewujudkan tata kehidupan negara yang adil, sejahtera, dan damai serta menjamin kedudukan hukum yang sama bagi setiap warga negara. Selain itu, Indonesia merupakan salah satu Negara yang berkembang, terdiri dari ribuan pulau dan beraneka ragam budaya, lautan yang luas, dan sumber daya alam yang melimpah.

Berdasarkan perkembangan yang terjadi mendorong pemerintah untuk melakukan perubahan di berbagai sektor demi peningkatkan pendapatan negara agar dapat membiayai pembangunan nasional Cahyadi, I Made Wahyu dan Jati, (2016).

Pembangunan nasional yang berlangsung secara terus menerus dan berkesinambungan diperlukan untuk meningkatkan kesejahteraan masyarakat. Masalah pembiayaan menjadi sangat vital dalam melaksanakan pembangunan nasional tersebut. Pemerintah membutuhkan dana yang besar untuk melaksanakan pembangunan nasional.

Menurut Ruyadi dalam Utama, (2013) salah satu upaya yang dapat dilakukan oleh pemerintah Indonesia dalam mewujudkan pembangunan nasional yaitu dengan menggali sumber dana berupa pajak. Pajak menjadi salah satu sumber pendanaan dalam pelaksanaan tanggung jawab negara dalam mengatasi masalah sosial, meningkatkan kesejahteraan, meningkatkan kemakmuran serta menjadi kontrak sosial antara warga negara dengan pemerintah.

Undang-Undang Republik Indonesia Nomor 19 Tahun 2000 tentang Penagihan Pajak dengan Surat Paksa, dimana pada Bab I Ketentuan Umum Pasal 1 ayat 1 menegaskan, Pajak adalah semua jenis pajak yang dipungut oleh Pemerintah Pusat, termasuk Bea Masuk dan Cukai, dan pajak yang dipungut oleh Pemerintah Daerah, menurut Undang-Undang dan Peraturan Daerah.

Pajak wajib dibayar oleh seseorang atau badan yang memiliki sesuatu yang harus di pajak, sebagaimana ditegaskan dalam Undang-Undang Republik Indonesia Nomor 19 Tahun 2000 tentang Penagihan Pajak dengan Surat Paksa, dimana pada Bab I Ketentuan Umum Pasal 1 ayat 2 ditegaskan, Wajib Pajak adalah orang pribadi atau badan yang menurut ketentuan peraturan perundang-undangan perpajakan ditentukan untuk melakukan kewajiban perpajakan, termasuk pemungut pajak atau pemotong pajak tertentu.

Pajak yang merupakan kewajiban yang harus dibayar oleh seseorang atau badan, pajak ialah pungutan warga negara kepada negaranya yang dapat dipaksakan dan akan menjadi hutang bagi yang 
berkewajiban membayar pajak sesuai dengan peraturan Undang-Undang dengan tidak dapat memperoleh imbalan yang langsung bisa ditunjuk dan dipakai dalam pembiayaan yang negara. Tetapi pada kenyataannya di Indonesia sendiri, masih banyak terjadi keterlambatan pembayaran pajak atau bahkan tidak membayar pajak sehingga kejadian ini berdampak pada perkembangan negara karena kurang sadarnya masyarakat dalam membayar pajak. Mereka pikir dengan membayar pajak mereka jadi rugi, karena mereka mengira bahwa hanya orang yang berkuasa saja yang dapat menikmati hasil pajak. Padahal, mereka keliru, membayar pajak pada waktunya akan berdampak baik bagi kehidupan mereka juga, terutama kehidupan menyangkut berbangsa dan bernegara. Jadi pajak menjadi kewajiban dan kepatuhan bagi orang pribadi atau badan yang memiliki ketentuan wajib pajak.

Menurut Yadnyana dan Sudiksa, (2011) kepatuhan wajib pajak merupakan sikap pada fungsi pajak, konstelasi dari komponen kognitif, efektif dan konatif yang mempunyai interaksi memahami, merasakan dan berperilaku terhadap makna dan fungsi pajak.

Kepatuhan wajib pajak merupakan sikap pemenuhan kewajiban membayar pajak yang dilakukan oleh wajib pajak atau pembayar pajak dalam memberikan kontribusinya dalam pembangunan bangsa dan negara, selain itu kepatuhan wajib pajak juga bisa menjadi penunjang Pendapatan Asli Daerah (PAD). Pajak selain bersifat wajib pajak juga bersifat memaksa. Kepatuhan wajib pajak menjadi hal yang penting karena Indonesia memiliki sistem perpajakan Self Asessment di mana dalam prosesnya mutlak memberikan kepercayaan kepada wajib pajak untuk menghitung, membayar dan melaporkan kewajiban pajaknya.

Menteri Keuangan dalam salah satu berita online, beliau mengakui bahwa kepatuahan wajib pajak di Indonesia masih menjadi masalah dan ini merupakan pekerjaan rumah yang harus diselesiakan. beliau mengatakan bahwa rasio pajak Indonesia masih rendah yang berada di angka 10,78 persen, ini lebih rendah bila dibandingkan dengan rasio pajak di Malaysia dan Singapura yang lebih tinggi dari Indonesia yaitu berada di level 14-15 persen. Adapun rasio pajak yang rendah itu sempat membuat Sri Mulyani malu. Karena, saat beliau masih menjabat Direktur Pelaksana Bank Dunia, beliau pernah melakukan kajian guna menentukan standar rasio pajak dari salah satu negara.

Pentingnya pajak bagi negara demi mewujudkan keadilan dan kesejahteraan bagi setiap warga negara. Karena itulah, setiap warga negara haruslah membayar pajak yang berdasarkan Undang-Undang 
nomor 16 tahun 2009 tentang ketentuan umum dan tata cara perpajakan.

Berbagai macam permasalahan yang terjadi, salah satunya di wilayah Kabupaten Mamuju seperti masalah dalam perpajakan yang terletak pada sejauh mana kesadaran masyarakat untuk memenuhi kewajiban pajaknya sesuai perundang-undangan yang berlaku, dimana masih banyak masyarakat yang kurang patuh dalam membayar pajak seperti menunggak pembayaran pajak, bahkan ada yang memang kurang peduli terhadap kewajibannya dalam membayar pajak kendaraan bermotornya. Sehingga hal ini menjadi dasar peneliti untuk melakukan analisis lebih jauh mengenai kesadaran wajib pajak pada kepatuhan wajib pajak baik dari aspek internal ataupun eksternal dalam meningkatkan kepatuhan wajib pajak warga Kabupaten Mamuju, agar kepatuhan wajib pajak yang ada di Kabupaten Mamuju ke depannya bisa lebih baik lagi.

Administrasi keuangan Negara bagian dari ilmu ekonomi dimana mengkaji tentang kegiatan pemerintah di bidang ekonomi terutama pada sektor penerimaan dan pengeluaran serta pengaruhnya didalam perekonomian tersebut. Pengaruh-pengaruh itu terutama terhadap pencapaian tujuantujuan kegiatan ekonomi seperti pertubuhan ekonomi, stabilitas harga, distribusi penghasilan yang lebih merata, peningkatan efisiensi, dan penciptaan kesempatan kerja Suparmoko, (2008).
Definisi Administrasi keuangan Negara bagian dari ilmu ekonomi dimana mengkaji tentang kegiatan pemerintah di bidang ekonomi terutama pada sektor penerimaan dan pengeluaran serta pengaruhnya didalam perekonomian tersebut. Pengaruh-pengaruh itu terutama terhadap pencapaian tujuan-tujuan kegiatan ekonomi seperti pertubuhan ekonomi, stabilitas harga, distribusi penghasilan yang lebih merata, peningkatan efisiensi, dan penciptaan kesempatan kerja Suparmoko, (2008). Dari defenisi diatas melihat bahwa administrasi keuangan negara bukan hanya tentang penerimaan dan pengeluaran tetapi juga tentang pengaruhnya terhadap berbagai macam kegiatan ekonomi.

Ruang Lingkup Keuangan negara meliputi negara memiliki hak untuk memungut pajak, mengeluarkan uang, mengedarkan dan melakukan pinjaman uang. Sudah menjadi kewajiban negara untuk menyelenggarakan pelayanan umum pemerintahan negara dan membayar tagihan pihak ketiga, Penerimaan Negara, hak pemerintah pusat yang diakui sebagai penembah nilai kekayaan bersih. Meliputi pajak, bukan pajak, dan hibah. Pengeluaran negara, penerimaan daerah dan pengeluaran daerah, kekayaan negara atau kekayaan daerah yang dikelolah sendiri atau oleh pihak lain baik itu uang, surat berharga, utang-piutang, barang, ataupun hak lain yang bernilai uang, termasuk kekayaan 
yang dipisahkan pada perusahaan negara atau perusahaan daerah, kekayaan pihak lain yang dikuasai oleh pemerintah dalam rangka penyelenggaraan tugas pemerintahan atau kepentingan umum, kekayaan pihak lain diperoleh dengan menggunakan fasilitas pemerintah.

Keuangan Negara dalam UndangUndang No. 17 tahun 2003 pasal 1 ayat 1 ialah semua hak dan kewajiban negara yang dapat dinilai dengan uang, serta segala sesuatu baik berupa uang maupun berupa barang yang dapat dijadikan milik Negara berhubung dengan pelaksanaan hak dan kewajiban tersebut. Dalam penjelasan Undang-Undang Nomor 17 Tahun 2003 tentang Keuangan Negara bahwa pendekatan yang digunakan dalam merumuskan Keuangan Negara yaitu dari sisi objek, subjek, proses, dan tujuan. Dari defenisi tersebut menyimpulkan bahwa semua hak dan kewajiban yang bernilai uang dapat dijadikan milik negara.

Dari pernyataan diatas bahwa dari sisi objek, yang dimaksud dengan Keuangan Negara meliputi segala hak dan kewajiban negara yang berniali uang, kebijakan dan kegiatan dalam bidang fiskal, moneter dan pengelolaan kekayaan negara, serta semua yang berupa uang ataupun berupa barang yang bisa menjadi milik negara untuk pelaksaaan hak dan kewajiban. Dari sisi subjek, yang dimaksud dengan keuangan negara meliputi seluruh subjek yang memiliki atau menguasai objek sesuai pernyataan diatas, yaitu pemerintah pusat dan daerah, perusahaan negara atau daerah, ataupun badan yang berkaitan dengan keuangan negara. Dari sisi proses, Keuangan negara mencakup seluruh rangkaian kegiatan yang berkaitan dengan pengelolaan objek seperti yang tersebut diatas, perumusan kebijakan dan pengambilan keputusan hingga pertanggunggjawaban. Dari sisi tujuan, Keuangan negara meliputi seluruh kebijakan, kegiatan serta hubungan hukum yang memiliki kaitan dengan pemilikan dan/atau penguasaan objek seperti disebutkan di atas untuk kepentingan penyelenggaraan pemerintahan negara.

Sebagaimana defenisi keuangan negara berdasarkan pendekatan objek, dapat dilihat bahwa cakupan hak dan kewajiban yang bernilai uang diperluas, termasuk kebijakan dan kegiatan dibidang fiskal, moneter dan pengelolaan kekayaan negara yang dipisahkan. Dengan demikian, bidang pengelolaan keuangan negara dapat dikelompokkan dalam: a) Sub bidang Pengelolaan Fiskal, b) Sub bidang Pengelolaan Moneter, c) Sub bidang Pengelolaan Kekayaan Negara Yang Dipisahkan.

Dalam pengelolaan keuangan negara pada sub bidang fiskal, kebijakan serta kegiatan yang memiliki keterkaitan dengan 
pengelolaan Anggaran Pendapatan dan Belanja Negara (APBN) dari penetapan Arah dan Kebijakan Umum (AKU), penetapan strategi dan prioritas pengelolaan APBN, penyusunan anggaran yang dilakukan oleh pemerintah, pengesahan anggrana yang dilakukan DPR, pelaksanaan, pengawasan, dan penyusunan Perhitungan Anggaran Negara(PAN) hingga pengesahan PAN menjadi undangundang. Pengelolaan keuangan negara sub bidang pengelolaan moneter berkaitan dengan kebijakan dan pelaksanaan kegiatan sektor perbankan dan jalannya moneter baik itu didalam negeri ataupun diluar negeri maupun luar negeri. Kemudian pengelolaan keuangan negara pada sub bidang kekayaan negara yang dipisahkan, memiliki kaitan dengan kebijakan serta pelaksanaan kegiatan pada sektor Badan Usaha Milik Negara/Daerah (BUMN/BUMD) berorientasi untuk mencari keuntungan (profit motive).

Menurut Suhendra, menyatakan bahwa tingkat kepatuhan wajib pajak badan, pemeriksaan pajak, dan pajak penghasilan terutang secara simultan memiliki pengaruh yang signifikan terhadap meningkatnya penerimaan pajak penghasilan badan. Hal tersebut menunjukkan bahwa jika diharapkan pendapatan pajak kendaraan bermotor penghasilan badan ingin ditingkatkan untuk menunjang kegiatan negara maka diperlukan pendekatan dari Kantor Pelayanan Pajak terhadap para wajib pajak yang meliputi pendekatan tingkat kepatuhan wajib pajak, pemeriksaan pajak dan pajak penghasilan terutang yang secara terus menerus dimonitoring dapat meningkatkan penerimaan pajak penghasilan secara signifikan. Ada 4 hal yang perlu diperhatikan dalam peningkatan pendapatan pajak, yaitu: (1) Perbaikan fasilitas dan infrastruktur; (2) Peningkatan pertahanan dan keamanan; (3) Kelestarian lingkungan hidup dan budaya; (4) Pengembangan alat transportasi massa.

\section{METODE PENELITIAN}

Penelitian yang dilakukan kurang lebih selama 2 (dua) bulan yang dimulai pada tanggal 09 November 2019 s/d 09 Januari 2020. Lokasi penelitian berada di Kantor Samsat Kabupaten Mamuju karena sesuai dengan latar belakang masalah kepatuhan wajib pajak masih kurang baik dan masih banyak pihak-pihak tertentu yang kurang perhatiannya dalam membayar pajak atau malas dalam membayar pajak.

Penelitian ini menggunakan jenis penelitian kuantitatif dengan alasan karena penelitian kuantitaif merupakan cara-cara dalam menguji teori khusus dengan cara meneliti pengaruh antar variabel. Variabelvariabel diukur dengan menggunakan instrumen - instrumen penelitian agar data 
yang berupa angka-angka dapat dianalisis menggunakan prosedur statistik.

Teknik analisis regresi sederhana digunakan untuk melihat besaran pengaruh variabel Kepatuhan Wajib Pajak terhadap variabel Peningkatan Pendapatan Pajak Kendaraan Bermotor pada Kantor Samsat Kabupaten Mamuju. Digunakan pula untuk membangun persamaan dan menggunakan persamaan tersebut untuk membuat perkiraan (prediction). Adapun rumus persamaan regresi sederhana yang digunakan dalam penelitian ini, adalah:

$\hat{Y}=a+b X$

Keterangan rumus:

Ý = variabel Kepatuhan Wajib Pajak

$\mathrm{X}=$ variabel Peningkatan Pendapatan

Pajak Kendaraan Bermotor

$\mathrm{a}=$ konstanta

$\mathrm{b}=$ koefisien regresi

\section{HASIL DAN PEMBAHASAN}

Sistem Administrasi Manunggal Satu Atap (Samsat) Kabupaten Mamuju yang berlokasi di Jl. Ahmad Yani, Binanga, Kec.
Mamuju, Kabupaten Mamuju, Sulawesi Barat. bertugas untuk mengadministrasi kebutuhan masyarakat bidang lalu lintas seperti perpanjang pajak STNK atau kendaraan bermotor.

Selain fungsi tersebut, Kantor Samsat ini juga melayani masyarakat untuk membuat SIM baik SIM A mobil, SIM C motor dan lainnya. Tersedia juga layanan perpanjangan SIM bagi masyarakat yang surat izin mengemudinya sudah kadaluarsa. Untuk perpajakan kendaraan, terdapat layanan samsat online dimana masyarakat dapat membayar pajak secara online melalui aplikasi e-samsat. Pada aplikasi tersebut, terdapat layanan untuk cek pajak kendaraan motor atau mobil, informasi syarat bayar pajak motor atau mobil, cek data pemilik kendaraan, cek data plat nomor kendaraan, informasi tarif perpanjangan pajak motor dan mobil dan lainnya. Di Kantor Samsat Kabupaten Mamuju juga terdapat layanan samsat keliling.

Karakteristik Responden

Tabel 1.

Persentasi Usia Responden

\begin{tabular}{|c|c|c|}
\hline Usia & Frekuensi & Persentase (\%) \\
\hline$\leq 20$ & 4 & 4,04 \\
\hline $21-30$ & 25 & 24,24 \\
\hline $31-40$ & 40 & 42,42 \\
\hline $41-50$ & 24 & 23,23 \\
\hline$>51$ & 6 & 6,06 \\
\hline Total & 99 & 100 \\
\hline
\end{tabular}

(Sumber : Data Primer diolah Tahun 2019)

Dari data responden pada tabel 4.1 responden paling banyak adalah responden diatas berdasarkan usia maka jumlah yang berusia 31-40 tahun yaitu sebanyak 40 
orang. Sementara jumlah responden paling

dibawah 20 tahun yaitu sebanyak 4 orang. sedikit adalah responden yang berusia

Tabel 2.

Persentasi Jenis Kelamin Responden

\begin{tabular}{|c|c|c|}
\hline Jenis Kelamin & Frekuensi & Persentase (\%) \\
\hline Laki-Laki & 75 & 75,76 \\
\hline Perempuan & 24 & 24,24 \\
\hline Total & 99 & 100 \\
\hline
\end{tabular}

(Sumber : Data Primer diolah Tahun 2019)

Dari data responden pada tabel 4.2 diatas berdasarkan jenis kelamin maka jumlah responden terbesar adalah responden laki-laki yaitu sebanyak 75 orang. Sementara jumlah responden terendah adalah responden perempuan yaitu sebanyak 24 orang.

Pada penelitian ini, tahap awal dari proses analisis data adalah melakukan uji validitas instrumen terlebih dahulu. Hal tersebut dimaksudkan untuk menjaga ketetapan suatu alat ukur dalam melakukan fungsi ukurannya. Kegunaan uji validitas untuk dapat mengetahui valid tidaknya suatu kuesioner yang merupakan alat ukur dalam penelitian ini, instrumen yang valid menggambarkan bahwa suatu instrumen benar - benar mampu dalam mengukur variabel - variabel yang akan di ukur dalam penelitian, serta mampu menunjukkan tingkat kesesuaian antara konsep penelitian dengan hasil pengukuran.

Pada uji validitas, peneliti menggambil sampel sebanyak 30 responden. Hal ini dimaksudkan untuk mengetahui valid atau tidaknya data sebelum data tersebut diolah. Uji validitas dilakukan untuk lebih mengefesienkan waktu dalam pengambian data yang ada dilapangan dan apabila sampel yang di dapat hasilnya valid secara keseluruhan, maka semua indikator telah mewakili semua instrumen. Namun bila terdapat sampel yang yang tidak valid dan tidak dapat mewakili indikator yang ada, maka instrumen tersebut akan dihapus atau dibuang. Adapun rumus yang digunakan oleh peneliti dalam uji validitas ini adalah dibantu dengan bantuan SPSS Versi 25. Item pernyataan tersebut valid apabila $r$ hitung $\geq \mathrm{r}$ tabel dan jika $\mathrm{r}$ hitung $\leq \mathrm{r}$ tabel, maka item atau butir instrumen dinyatakan tidak valid. Berdasarkan tabel 4.5 di atas hasil pengujian validitas instrumen Peningkatan Pendapatan Pajak Kendaraan Bermotor (Y) dapat di jelaskan bahwa dari 12 item pertanyaan smuanya valid, karena angka korelasi yang diperoleh dibawah taraf signifikan 5\% $(0,05)$ atau $r$ hitung $\geq r$ tabel. Rata - rata $\mathrm{r}$ hitung tabel di atas 
adalah 0,56 jadi semua pertanyaan dinyatakan valid.

Hasil pengujian reliabilitas istrumen yang hasilnya reliabel mengandung pengertian bahwa apabila instrumen pada suatu saat akan digunakan kembali untuk mengukur variabel yang sama, yaitu Peningkatan Pendapatan Pajak Kendaraan Bermotor (Y) maka hasilnya relative sama. Dengan kata lain konsistensi dari hasil pengukuran dengan menggunakan instrumen yang sama.

\section{Analisis Variabel Kepatuhan Wajib Pajak (X)}

Menurut 99 responden mengenai

Kepatuhan Wajib Pajak yaitu:

$\frac{\text { Jumlah skor variabel }(X)}{\text { Jumlah skor tertinggi }} \times 100 \%=\frac{\mathbf{1 0 9 5 8}}{\mathbf{1 4 8 5 0}} \times$ $100 \%=73,7 \%$

Dari perhitungan dan keterangan di atas dapat diketahui bahwa Kepatuhan
Wajib Pajak di Kantor Samsat Kabupaten Mamuju berada pada pada angka 61\% $80 \%=$ Baik. Hal ini terlihat dari nilai $73,7 \%$ termasuk kategori baik.

Analisis Variabel Peningkatan Pendapatan Pajak Kendaraan Bermotor (Y)

Menurut 99 responden mengenai

Kepatuhan Wajib Pajak yaitu:

$\frac{\text { Jumlah skor variabel }(X)}{\text { Jumlah skor tertinggi }} \times 100 \%=\frac{7756}{\mathbf{9 9 0 0}} \times 100 \%$ $=78,3 \%$

Dari perhitungan dan keterangan di atas dapat diketahui bahwa Pendapatan Peningkatan Pendapatan Pajak Kendaraan Bermotor di Kantor Samsat Kabupaten Mamuju berada pada pada angka 61\% $80 \%=$ Baik. Hal ini terlihat dari nilai $78,3 \%$ termasuk kategori baik.

Tabel 3.

Uji Korelasi

\begin{tabular}{|c|c|}
\hline Interval Koefisien & Tingkat Hubungan \\
\hline $0,00-0,199$ & Sangat Rendah \\
\hline $0,20-0,399$ & Rendah \\
\hline $0,40-0,599$ & Sedang \\
\hline $0,60-0,799$ & Kuat \\
\hline $0,80-1,000$ & Sangat Kuat \\
\hline
\end{tabular}

Korelasi antara X dan Y sebesar 0,7, artinya terdapat korelasi yang kuat antara Pengaruh Kepatuhan Wajib Pajak (X) dan Peningkatan Pendapatan Pajak Kendaraan
Bermotor (Y), dengan arah positif. Dari perbandingan tersebut rhitung ternyata menunjukkan angka sebesar 0,7 lebih besar dari pada rtabel 0,3. Jadi jika rhitung 
> rtabel maka Ho di tolak, $\mathrm{H} \alpha$ di terima artinya terdapat pengaruh yang kuat antara Kepatuhan Wajib Pajak (X) dan Peningkatan Pendapatan Pajak Kendaraan Bermotor (Y).

\section{Kepatuhan Wajib Pajak Kendaraan Bermotor}

Hasil penelitian dalam persentase pencapaian dan kategori per indikator kepatuhan wajib pajak terhadap 99 responden yang ada di Kabupaten Mamuju yaitu: Kewajiban untuk mendaftarkan diri, didominasi dengan jawaban responden "Setuju" dengan persentase tertinggi 44,2\% dan "Tidak Setuju" dengan persentase terendah $6 \%$, hal tersebut diperkuat berdasarkan hasil pengamatan peneliti pada saat melakukan pengumpulan data terlihat para wajib pajak mendaftrakan diri untuk bisa membayar pajak. Kewajiban mengisi dan menyampaikan surat, didominasi dengan jawaban responden "Setuju" dengan persentase tertinggi 52\% dan "Sangat Tidak Setuju" dengan persentase terendah $1,5 \%$, hal tersebut dikarenakan penting untuk melakukan hal tersebut selain karena aturan juga untuk memudahkan wajib pajak dalam membayar pajak. Kewajiban membayar atau menyetor pajak, didominasi dengan jawaban responden "Kurang Setuju" dengan persentase tertinggi $40,6 \%$ dan "Sangat Tidak Setuju" dengan persentase terendah 1,3\%, berdasarkan hasil pengamatan peneliti masih banyak wajib pajak yang memang kurang patuh dalam membayar atau menyetor pajak yang dikarenakan oleh berbagai macam faktor. Kewajiban membuat pembukuan atau pencatatan, didominasi dengan jawaban responden "Setuju" dengan persentase tertinggi 56,4\% dan "Tidak Setuju" dengan persentase terendah 4,2\%, hal ini dikarenakan berdasarkan hasil pantauan peneliti bahwa sebagian besar responden melakukan pembukuan atau pencatatan pajaknya. Kewajiban menaati pemeriksaan pajak, didominasi dengan jawaban responden "Setuju" dengan persentase tertinggi 50,4\% dan "Sangat Tidak setuju" dengan persentase terendah 3,3\%, hal tersebut diperkuat berdasarkan hasil pantauan peneliti, sebahagian responden taat ketika ada petugas yang ingin melakukan pemeriksaan pajak dan ada juga yang masih merasa takut jika diperiksa petugas pajak. Kewajiban melakukan pemotongan atau pungutan pajak, didominasi dengan jawaban responden "Setuju" dengan persentase tertinggi 60,2\% dan "Sangat Tidak Setuju" dengan persentase terendah 2,2\%, hal ini sesuai dengan pengamatan peneliti, para responden bersedia melakukan pemotongan atau pungutan pajak.

Jika di rata - ratakan berdasarkan hasil perhitungan persentase pencapaian 
dalam analisis variabel Kepatuhan Wajib Pajak (X) maka diketahui Kepatuhan Wajib Pajak Kendaraan Bermotor yang ada di Kabupaten Mamuju masuk ke dalam kategori Baik (73,7\%). Dari hasil tersebut menunjukkan bahwa sebagian besar wajib pajak telah melaksanakan kewajibannya dan patuh dalam membayar atau menyetor pajak. Dan selebihnya tidak patuh dalam membayar pajak.

Menurut peneliti dari hasil penelitian tersebut, meskipun kepatuhan wajib pajak masuk dalam kategori baik tapi masih ada beberapa indikator yang perlu diberikan perhatian lebih untuk memaksimalkan kepatauhan wajib pajak seperti pada indikator mendaftarkan diri sesuai dengan peraturan, menyiapkan dokumen untuk membayar pajak, bersedia memenuhi kewajiban atas tunggakan pajak, mengalokasikan dana untuk pajak, dan merasa takut bila berhubungan dengan pemeriksaan pajak. Jadi beberapa indikator kepatuhan tersebut perlu adanya perhatian lebih untuk meningkatkan pendapatan pajak. Hal ini senada dengan pendapat faktor yang mempengaruhi penerimaan pajak suatu negara diantaranya adalah tingkat kepatuhan wajib pajak masyarakat di negara tersebut. Apabila masyarakat semakin patuh akan peraturan perpajakan maka tentunya akan berimbas kepada peningkatan pendapatan pajak dalam negeri.

\section{Peningkatan Pendapatan Pajak Kendaraan Bermotor}

Hasil penelitian dalam persentase pencapaian dan kategori per indikator peningkatan pendapatan pajak kendaraan bermotor terhadap 99 responden yang ada di Kabupaten Mamuju yaitu: Perbaikan fasilitas dan infrastruktur, didominasi dengan jawaban responden "Setuju" dengan persentase tertinggi 52\% dan "Sangat Tidak Setuju" dengan persentase terendah $1 \%$. Peningkatan pertahanan dan keamanan, didominasi dengan jawaban responden "Setuju" dengan persentase tertinggi 57,5\% dan "Sangat Tidak Setuju" dengan persentase terendah $0,4 \%$. Kelestarian lingkungan hidup dan budaya, didominasi dengan jawaban responden "Setuju" dengan persentase tertinggi $53,5 \%$ dan "Sangat Tidak Setuju" dengan persentase terendah 1,1\%. Dan Pengembangan alat transfortasi massa, didominasi dengan jawaban responden "Setuju" dengan persentase tertinggi 51,1\% dan "Sanat Tidak Setuju" dengan persentase terendah $1,7 \%$.

Jika di rata - ratakan berdasarkan hasil perhitungan persentase pencapaian dalam analisis variabel Peningkatan Pendapatan Pajak Kendaraan Bermotor (Y) maka diketahui peningkatan pendapatan pajak kendaraan bermotor yang ada di Kantor Samsat Kabupaten Mamuju masuk dalam kategori Baik (78,3\%). Peningkatan 
Pendapatan Pajak Kendaraan Bermotor berpengaruh besar terhadap terhadap berbagai macam hal, seperti pembangunan, perbaikan sarana dan infrakstruktur, dan lain sebaginya yang ada di Kabupaten Mamuju, apabila pendapatan pajak menurun maka pembangunan juga akan kurang efektif dilaksanakan. Oleh sebab itu, faktor - faktor yang dapat mempengaruhi Peningkatan Pendapatan Pajak harus diperhatikan karena akan berdampak langsung terhadap perkembangan dan pembangunan di Kabupaten Mamuju, baik itu terhadap masyarakatnya ataupun wilayahnya.

Jadi, peneliti menilai bahwa peningkatan pendapatan pajak yang ada di Kabupaten Mamuju harus lebih ditingkatkan lagi sehingga kedepannya pembangunan yang akan dilaksanakan lebih baik lagi. Beberapa indikator masih perlu dimaksimalkan agar dapat tercapai hasil yang lebih baik lagi seperti pada indikator Kelestarian lingkungan hidup dan budaya dan indikator Pengembangan alat transfortasi massa, sekitar 20\% lebih responden menyatakan kurang setuju dan tidak setuju.

\section{Pengaruh Kepatuhan Wajib Pajak terhadap Peningkatan Pendapatan Pajak}

\section{Kendaraan Bermotor}

Berdasarkan hasil analisis data yang telah dilakukan dapat ditunjukkan pada tabel 4.73 diketahui nilai thitung sebesar $10,349>$ tabel 1,988 dan diperoleh nilai signifikansi sebesar $0,000 \leq 0,05$, perbandingan tersebut mengartikan Ho ditolak dan $\mathrm{H}_{1}$ diterima maka disimpulkan terdapat hubungan yang positif dan signifikan sehingga adanya Pengaruh Kepatuhan Wajib Pajak (X) terhadap Peningkatan Pendapatan Pajak Kendaraan Bermotor (Y) di Kantor Samsat Kabupaten Mamuju.

Hasil perhitungan tersebut diperkuat berdasarkan nilai koefisien korelasi (r) berdasarkan tabel 4.70 sebesar 0,741 menunjukkan bahwa terdapat keeratan yang kuat antara variabel Kepatuhan Wajib Pajak dan Peningkatan Pendapatan Pajak Kendaraan Bermotor. Kemudian nilai koefisien determinan (R2) berdasarkan tabel 4.72 sebesar 0,549 dan sumbangan efektif Kepatuhan Wajib Pajak sebesar $54,9 \%$. Sehingga harga tersebut menjelaskan pula bahwa terdapat pengaruh kepatuhan wajib pajak terhadap peningkatan pendapatan pajak kendaraan bermotor, persentase pengaruhnya sebesar $54,9 \%$ dan sisanya $45,1 \%$ dipengaruhi oleh variabel lain yang tidak diteliti dalam 
penelitian ini. Hasil penelitian tersebut sesuai dengan pendapat Widjaja, (2002) kesadaran Wajib Pajak diperlukan untuk meningkatkan penerimaan pajak. Dan menurut Anggriawan, (2015) self assessment system berpengaruh positif terhadap penerimaan pajak.

Menurut peneliti pada penelitian ini, terdapat pengaruh kepatuhan wajib pajak terhadap peningkatan pendapatan pajak di Kabupaten Mamuju sesuai dengan hasil penelitian di atas. Kepatuhan wajib pajak yang ada di Kabupaten Mamuju sudah cukup baik tapi meskipun begitu agar peningkatan pendapatan pajak lebih baik dari sebelumnya perlu untuk memaksimalkan kepatuhan wajib pajak, sehingga ke depannya pendapatan pajak bisa lebih baik. Dan juga demi untuk kepentingan bersama untuk baik pemerintah maupun masyarakat di Kabupaten Mamuju.

\section{KESIMPULAN}

Kepatuhan Wajib Pajak Kendaraan Bermotor di Kantor Samsat Kabupaten Mamuju berdasarkan hasil perhitungan persentase pencapaian dalam analisis variabel Kepatuhan Wajib Pajak (X) maka diketahui Kepatuhan Wajib Pajak Kendaraan Bermotor yang ada di Kabupaten Mamuju masuk ke dalam kategori Baik (73,52\%). Dari hasil tersebut menunjukkan bahwa sebagian besar wajib pajak telah melaksanakan kewajibannya dan patuh dalam membayar atau menyetor pajak. Dan selebihnya tidak patuh dalam membayar pajak. Tapi meskipun masuk dalam kategori baik tidak bisa dipungkiri bahwa ada beberapa indikator yang perlu diberikan perhatian lebih untuk meningkatkan kepatauhan wajib pajak seperti pada indikator mendaftarkan diri sesuai dengan peraturan, menyiapkan dokumen untuk membayar pajak, bersedia memenuhi kewajiban atas tunggakan pajak, mengalokasikan dana untuk pajak, dan merasa takut bila berhubungan dengan pemeriksaan pajak. Jadi beberapa indikator kepatuhan tersebut perlu adanya perhatian lebih untuk meningkatkan pendapatan pajak.

Peningkatan Pendapatan Pajak Kendaraan Bermotor di Kantor Samsat Kabupaten Mamuju berdasarkan hasil perhitungan persentase pencapaian dalam analisis variabel Peningkatan Pendapatan Pajak Kendaraan Bermotor (Y) maka diketahui peningkatan pendapatan pajak kendaraan bermotor yang ada di Kantor Samsat Kabupaten Mamuju masuk dalam kategori Baik $(78,50 \%)$ atau dapat disimpulkan bahwa pendapatn pajak di Kantor Samsat Kabupaten Mamuju sudah cukup baik.

Terdapat hubungan yang positif dan signifikan sehingga adanya Pengaruh Kepatuhan Wajib Pajak (X) terhadap Peningkatan Pendapatan Pajak Kendaraan 
Bermotor (Y) di Kantor Samsat Kabupaten Mamuju sebesar 54,9\% dan sisanya 45,1\% dipengaruhi oleh variabel lain yang tidak diteliti dalam penelitian ini. Dari hasil penelitian diatas diketahui bahwa masih ada beberapa indikator penting yang masih perlu adanya perhatian lebih untuk meningkatkan pendapatan pajak di Kabupaten Mamuju.

Perlunya perhatian yang lebih pada indikator kewajiban membayar atau menyetor pajak yang masih kurang baik karena ini menjadi variabel penting dalam peningkatan pendapatan pajak kendaraan bermotor di Kabupaten Mamuju.

Perlunya sosialisasi yang harus sering dilakukan menyangkut kepatuhan dan keawajiban membayar pajak agar para wajib pajak mempunyai kesadaran lebih dalam membayar pajak.

\section{DAFTAR PUSTAKA}

Anggriawan, A. (2015). Pengaruh Self Assessment System dan Efektivitas Administrasi Perpajakan terhadap Penerimaan Pajak. perpajakan.

Cahyadi, I Made Wahyu dan Jati, I. K. (2016). Pengaruh Kesadaran, Sosialisasi, Akuntabilitas Pelayanan Publik dan Sanksi Perpajakan pada Kepatuhan Wajib Pajak Kendaraan Bermotor. E-Jurnal Akuntansi Universitas Udayana, $h: 2342-234$.

Suhendra, E. S. 2010. (2010). Pengaruh Tingkat Kepatuhan Wajib Pajak Badan terhadap Peningkatan Penerimaan Pajak Penghasilan Badan. Jurnal Ekonomi Bisnis Fakultas Ekonomi Universitas Gunadarma, Vol.15, $h$ :
Suparmoko, M. (2008). Keuangan Negara dalam Teori dan Praktek. BPFFE.

Utama, I. W. M. (2013). Pengaruh Kualitas Pelayanan, Sanksi Perpajakan dan Biaya Kepatuhan terhadap Kepatuhan Wajib Pajak. E-Jurnal Fakultas Ekonomi Universitas Udayana (Unud), Bali, Indonesia, $h: 453$.

Widjaja. (2002). Komunikasi dan Hubungan Masyarakat. PT. Bumi Aksara.

Yadnyana dan Sudiksa. (2011). Pengaruh Peraturan Pajak Serta Sikap Wajib Pajak Pada Kepatuhan Wajib Pajak Koperasi di Kota Denpasar. Fakultas Ekonomi Universitas Udayana, 17(2):h:19. 